\title{
WARSZTAT TŁUMACZA SĄDOWEGO W TRANSLACJI CHORWACKO-POLSKICH TERMINÓW PRAWNYCH
}

\author{
A Sworn Translator's Skills in Croatian-Polish Translation of Legal Terminology
}

Keywords: translation, lexicography, Polish language, Croatian language, law

Contact: Uniwersytet Jana Kochanowskiegow Kielcach; piotrczajkowski@poczta.onet.pl

\section{Zasady wykonywania zawodu tlumacza sądowego w Polsce i Chorwacji.}

W Polsce wykonywanie zawodu tłumacza przysięgłego reguluje Ustawa z dnia 25 listopada 2004 roku, wg której tłumacz przysięgły jest uprawniony do:

1) sporządzania i poświadczania tłumaczeń z języka obcego na język polski, z języka polskiego na język obcy, a także do sprawdzania i poświadczania tłumaczeń w tym zakresie, sporządzonych przez inne osoby;

2) sporządzania poświadczonych odpisów pism w języku obcym, sprawdzania i poświadczania odpisów pism, sporządzonych w danym języku obcym przez inne osoby;

3) dokonywania tłumaczenia ustnego.

W dalszej części ustawy czytamy o tym, że do poświadczania tłumaczeń oraz poświadczania odpisów pism wydawanych w formie pisemnej tłumacz przysięgły używa pieczęci, zawierającej w otoku jego imię i nazwisko, a w środku wskazanie języka, w zakresie którego ma uprawnienia, oraz pozycję na liście tłumaczy przysięgłych.

W prawie chorwackim zawód tłumacza reguluje Pravilnik o stalnim sudskim tumačima wydany przez Ministra Sprawiedliwości Republiki Chorwackiej i ogłoszony w Dzienniku Ustaw pod Nr 150/05 i 16/07. W odróżnieniu od tłumaczy polskich, tłumacze chorwaccy powoływani są na czteroletnią kadencję $z$ możliwością wnioskowania o jej przedłużenie. Na liście tłumaczy sądowych w Chorwacji może znaleźć się osoba która posiada wykształcenie wyższe, zna biegle język obcy w obszarze sądu którego językiem urzędowym jest język chorwacki. Musi posiadać 
również wiedzę $\mathrm{z}$ zakresu sądownictwa, administracji państwowej oraz znać terminologię prawną. Postępowanie $\mathrm{w}$ sprawie powołania thumacza sądowego rozpoczyna się od wniosku zainteresowanego, skierowanym do prezesa sądu okręgowego lub sądu gospodarczego właściwego ze względu na miejsce zamieszkania. Do wniosku dołącza się życiorys, dokumenty potwierdzające narodowość, wykształcenie i znajomość języka obcego. Potwierdzeniem znajomości języka, który kandydat deklaruje, jest dyplom ukończenia studiów wyższych filologicznych lub certyfikat językowy (poziom C2). Przed rozpatrzeniem wniosku prezes właściwego sądu kieruje kandydata na test $\mathrm{z}$ wiedzy o strukturze sądownictwa $\mathrm{i}$ administracji państwowej oraz znajomości terminologii prawniczej. Testu nie musi zdawać absolwent prawa. Przed wydaniem decyzji kandydaci odbywają również aplikacje pod czujnym okiem doświadczonych tłumaczy przysięgłych. Po wydaniu decyzji tłumacz otrzymuje podobnie jak w Polsce repertorium i okrągłą pieczęć imienną z informacją o języku, dla którego został ustanowiony.

\section{Specyfika thumaczeń prawnych.}

Tłumacze sądowi mają do czynienia $\mathrm{z}$ tłumaczeniami mającymi cechy wspólne z każdym innym tłumaczeniem. Te jednak łączą ze sobą nie tylko wiedzę językową, ale także szerszą wiedzę z zakresu prawa, historii, legislacji itp. Definiując przekład prawny Barak stwierdził, że jest to „racjonalne działanie, nadające znaczenie tekstowi prawnemu” oraz „działalność intelektualną, która zajmuje się określeniem normatywnego przesłania, jakie wyłania się z tekstu" (Barak 2005: 3). Tłumaczenie prawne musi zatem posiadać charakterystyczne cechy. Mam tu na myśli strukturę gramatyczną zdań, specyficzne słownictwo i wzorce leksykalne. Aby zrozumieć zdanie, potrzebna jest wiedza kognitywna. Składniki zdaniowe (jawne i niejawne) budują złożoną propozycję, znajdując się w pewnych relacjach i tworząc jasną hierarchię. Zdanie o strukturze logicznej to wyraźnie wyrażona propozycja, która jest uzupełniona ukrytym znaczeniem zawartym w zdaniu. Zgodnie z opracowaną przez Europejski Komitet Normalizacyjny w 2006 r. Europejską Normą EN 15038 „Usługi thumaczeniowe. Wymagania dotyczące świadczenia usług" Artur Kubacki wymienia elementy, na jakie powinien zwrócić uwagę thumacz podczas przekładu pisemnego. Rozróżnia on siedem elementów: „1. Terminologię: zgodność z terminologią specjalistyczną danej dziedziny i terminologią stosowaną przez klienta lub inną dostarczoną terminologią, jak również zachowanie spójności terminologicznej w całym tłumaczeniu; 2. Gramatykę: składnię, ortografię, interpunkcję, typografię, znaki diakrytyczne; 3. Leksykę: spójność leksykalną i frazeologię; 4. Styl: zgodność $\mathrm{z}$ własnymi lub otrzymanymi od klienta wytycznymi dotyczącymi stylu, w tym 
odnoszącymi się do rejestru językowego i wariantu języka; 5. Aspekty kulturowe: zwyczaje lokalne i normy regionalne; 6. Formatowanie; 7. Grupę docelową i cel thumaczenia" (Kubacki 2008: 155).

Tłumaczenie przysięgłe musi ponadto być wierne, przejrzyste i rzetelne. Użyte w nim terminy muszą być zastosowane jednakowo w całym dokumencie. Nie ma znaczenia, czy tekst jest thumaczony z jednego języka na inny oparty na tych samych czy innych systemach prawnych. Musi zawierać kod języka docelowego, a nie tylko przeniesienie słów z tekstu źródłowego do tekstu docelowego. Tłumaczenie prawne zakłada nie tylko interpretację semantyczną, ale uwzględnia też czynniki pragmatyczne. Tłumacz musi trzymać się pojęcia równoważnego pojęciu języka docelowego, w tym kontekstu w tekście źródłowym i kontekstu w tekście docelowym. Nie może też zapomnieć o pragmatyzmie międzykulturowym (zob. Wierzbicka 2003), ponieważ tłumaczenie tekstu prawnego sporządzonego w danym kraju jest głęboko zakorzenione w jego kulturze i nie powinno być postrzegane jako zjawisko odosobnione. Współczesna nauka zmierza dziś w kierunku interdyscyplinarności. W ten sposób tłumaczenie prawne łączy ze sobą wiedzę z zakresu nauk prawnych i językoznawstwa.

\section{Terminologia prawna jako podstawa ksztaltowaniu warsztatu tlumacza.}

Terminologia prawna używana jest nie tylko przez prawników lingwistów, leksykologów, ale także tłumaczy przysięgłych. Ci ostatni w swojej pracy często spotykają się $\mathrm{z}$ tekstami $\mathrm{z}$ zakresu postępowania karnego, cywilnego, administracyjnego, rodzinnego i opiekuńczego, rzadziej z prawa konstytucyjnego. „Można uznać, iż w thumaczeniu na język polski przede wszystkim należy zwracać uwagę na to, z jaką gałęzią prawa mamy do czynienia i przy uwzględnieniu tej wiedzy dokonywać wyboru odpowiednich ekwiwalentów funkcjonalnych" (Juszkiewicz 2012: 8). Terminologiczna interpretacja tekstu prawnego jest z natury bardzo wysublimowana, a tłumacz musi wziąć pod uwagę szerszy kontekst oryginału, który w tłumaczeniu prawnym (zarówno pisemnym, jak i ustnym) jest od dawna uznawany za bardzo ważny, niestety często $\mathrm{z}$ różnych przyczyn bywa zapominany i zaniedbywany. Konceptualna strona systemu terminologicznego odzwierciedla relacje, jakie istnieją między pojęciami w ramach określonego pola semantycznego. „Mając na myśli tłumaczenie tekstów prawniczych mówimy o tłumaczeniu z jednego języka prawniczego na drugi, przy czym nie stosuje się $\mathrm{w}$ języku docelowym terminologii potocznej, czy jakiejkolwiek terminologii pośredniej” (Groot 2002: 223). Szeroko rozumiane thumaczenia sądowe, oparte muszą być na doświadczeniu, kompetencjach i interdyscyplinarnej wiedzy thumacza. „Tłumacz sądowy jest zatem ekspertem 
w zakresie komunikacji transkulturowej, odpowiedzialnym za zapewnienie rozumienia i bycia zrozumianym (...)" (Kadrić 2009: 26). Szczególnie ważne przy porównawczej analizie terminologicznej języka polskiego i chorwackiego jest zwrócenie uwagi na stronę pojęciową. Podobnie jak $\mathrm{w}$ języku polskim również $\mathrm{w}$ języku chorwackim występuje wiele różnic między terminologią prawa cywilnego i karnego. Powód i pozwany to pojęcia prawa cywilnego, a podejrzany i oskarżony terminy z zakresu prawa karnego.

„W postępowaniu karnym dobór terminów jest uzależniony od etapu postępowania, a więc od tego czy chodzi o postępowanie przygotowawcze (śledztwo, dochodzenie) czy o postępowanie przed sądem oraz od rodzaju postępowania" (JopekBosiacka 2009: 213). Jak trafnie zauważa Pieńkos: „Tekst specjalistyczny wymaga od tłumacza znajomości danej dziedziny oraz zasad, rządzących sztuką przekładu. Znajomość terminologii zastosowanej w danej dziedzinie wiedzy lub tłumaczonym dziele naukowym jest - obok gruntownej znajomości języka oryginału i języka przekładu - jednym z podstawowych warunków osiągnięcia równowartościowego i pełnowartościowego przekładu dzieła (...) (Pieńkos 2003: 234). Należy wziąć pod uwagę, że tłumacz wykorzystuje w języku ojczystym wiedzę kognitywną w sposób nieświadomy wręcz automatyczny. Aby kształtować kompetencje społecznokulturowe, powinien więc stale pracować nad poszerzaniem wiedzy pojęciowej w języku docelowym. W tym celu niezwykle ważne jest poznanie systemów prawnoustrojowych funkcjonujących zarówno w Polsce, jak i w Chorwacji. Jest to bardzo ciekawe w szczególnie w drugim przypadku. System prawny w Chorwacji ewaluował na przestrzeni wieków kilkukrotnie. „Przeobrażenia prawno-ustrojowe w Jugosławii pod koniec lat osiemdziesiątych znalazły swój wyraz obok konstytucji federalnej w ustawach zasadniczych poszczególnych republik" (Wojnicki 2014: 14). Na problem ten należy również spojrzeć $\mathrm{z}$ aspektu języka. W Chorwacji forma državni odvjetnik (prokurator) tożsama z tą do 1929 roku. W Królestwie Serbów, Chorwatów i Słoweńców do 1941 roku używano terminu državni tužilac a po II wojnie światowej w Socjalistycznej Republice Jugosławii był to javni tužilac. W funkcjonującej dziś w Chorwacji terminologii prawnej powrócono zdecydowanie do form sprzed 1929 roku i zrezygnowano $\mathrm{z}$ form funkcjonujących dziś $\mathrm{w}$ języku serbskim.

\section{Rodzaje tlumaczeń prawnych jako narzędzia warsztatu translatorskiego.}

Tłumaczenia ustne występują w pracy tłumacza sądowego równie często jak pisemne a nawet uzupełniają się wzajemnie. Ma to miejsce podczas przesłuchań, z których następnie sporządzane są protokoły i inne dokumenty wykorzystywane w dalszym 
postępowaniu. Najpopularniejszym typem przekładu, wyróżnionym przez współczesnych specjalistów z zakresu translatoryki, jest przekład automatyczny, zwany też maszynowym. Realizowany głównie za pomocą programów komputerowych. W praktyce sądowej, ze zrozumiałych powodów nie stosuje się jednak podobnej strategii, która nie zapewnia w odpowiedni sposób przekazania informacji. Chociaż teoretycznie możliwy, jest sposób takiego tłumaczenia, to w praktyce podobnie jak tłumaczenie interesmiotyczne (transmutacyjne) - nie znajduje zastosowania $\mathrm{w}$ tłumaczeniach $\mathrm{z}$ dziedzin prawa. Tłumacz często musi zmierzyć się za to $\mathrm{z}$ innym typem tłumaczeń. Najczęstszym z nich jest wspomniany już przez mnie wcześniej przekład konsekutywny, sekwencyjny, polegający na wysłuchaniu kilku zdań, zapamiętaniu ich (lub odnotowaniu), a następnie wypowiedzeniu przetłumaczonego tekstu. Tłumaczenia takie wykonywane są na potrzeby organów wymiaru sprawiedliwości. Zlecają je sądy, prokuratura czy policja. Mniej popularne, ale także mające miejsce w pracy tłumaczy sądowych, są tłumaczenia symultaniczne i konferencyjne wykorzystywane przy organizacji konferencji lub prezentacji dla dużej liczby osób. Uważa się, że takie tłumaczenia są najtrudniejsze ze względu na liczbę decyzji, jakie musi podjąć tłumacz w określonym czasie, szukając odpowiedniego słowa do przekazania informacji w języku docelowym. „Tłumacze sądowi są aktywnymi uczestnikami procesu karnego, mogącymi poprzez swoje działania bezpośrednio wpływać na jego przebieg, a nawet wynik" (Nartowska 2013: 125).

Należy tu zaznaczyć, że do przeprowadzenia tłumaczenia symultanicznego musi zostać zapewnione odpowiednie wyposażenie techniczne. Ze względu na sposób przekazywania informacji można wyróżnić tłumaczenia autorskie, wewnątrzjęzykowe, swobodne czy też diachroniczne. Ja chciałbym skupić się głównie na tłumaczeniach dokumentów urzędowych, sporządzanych przez tłumaczy przysięgłych, które mają taką samą moc prawną jak oryginał.

Interpretacja semantyczna implikuje znaczenie słów lub wyrażeń, które uważamy za najpowszechniej występujące w słownikach (najczęściej określane jako znaczenie podstawowe) lub znaczene niezależnie od kontekstu. Lessig podkreślał (Lessig 1993: 1178), że „znaczenie składa się z czegoś na pierwszym planie (tekst) i czegoś w tle (kontekst). Aby zachować znaczenie (zarówno językowe, jak i pozajęzykowe), oba plany muszą być możliwe do analizy. W słownikach terminologicznych często więcej uwagi poświęca się tylko językowej stronie, co prowadzi do błędów translatorskich. Podejście konceptualne jest ważne w przypadku tłumaczenia prawnego, ponieważ opiera się na specjalistycznej wiedzy z określonej dziedziny, tworzy podstawę dla wyważonej i znormalizowanej terminologii, ułatwia analizę porównawczą pojęć i znaków językowych między językami. Dobrze 
przygotowany thumacz nie będzie thumaczył terminu podejrzany jako oskarżony, w przypadku jeśli postępowanie nadal się toczy. W praktyce jednak organy sądowe często traktują podejrzanego jako oskarżonego ze względu na szybkość toczącego się postępowania, które jest nieprawidłowo określone pod kątem językowym a co gorsza prawnym. Należy zatem wziąć pod uwagę tego typu niuanse i nieścisłości.

\section{Problemy $z$ translacją tlumaczeń prawnych $w$ języku polskim i chorwackim.}

Odnosząc się do wyszukiwania, selekcji i wykorzystania terminów prawniczych w procesie tłumaczenia prawnego, należy podkreślić, że tłumacz zarówno w Polsce jak i w Chorwacji znajduje się w dość trudnej sytuacji, ponieważ do tej pory nie wydano specjalistycznych słowników polsko-chorwackich i chorwacko- polskich poświęconych terminom prawnym. Tłumaczenia są możliwe jedynie przy przy wykorzystaniu jednojęzycznych słowników terminów prawniczych polskich lub chorwackich. Wymienię tu Polski stownik terminów i pojęć prawniczych Zofiii KrzysztoforskiejWeisswasser wydany we Wiedniu w 1998 roku. W Chorwacji w Zagrzebiu w 2006 roku został opublikowany Opći pravni rjecnik autorstwa Marti Vidaković-Mucić a rok później ukazał się Pravni Leksikon Vladimira Pezo. Z dwujęzycznych słowników na uwagę zasługuje Stownik polsko-chorwacki wydany w Zagrzebiu w 2002 roku pod redakcją Milana Moguša i Nedi Pentarić oraz starszy wydany w Warszawie w roku 1987 dwutomowy Stownik serbsko-chorwacko polski Vilima Frančicia. Ze względu na różne koncepcje terminologiczne przedstawione $\mathrm{w}$ słownikach ogólnych terminologia prawnicza może być interpretowana w różny sposób, co budzi wiele niejasności.

Dla tłumaczy ze znajomością języka angielskiego dobrym rozwiązaniem będzie Engelsko-hrvatski rječnik prava, međunardnih odnosa, kriminalistike i forenzičnih znanosti, kriminologije i sigurnosti wydany w Zagrzebiu w 2004 autorstwa Milici Gačić.

Z powyższych przykładów widać, że słowników jest niewiele i często nie odpowiadają potrzebom prawników lingwistów czy thumaczy sądowych. Często zdarza się, że jest w nich zawartych zbyt mało haseł a terminy są potoczne lub zbieżne ze sobą. Tak jest w przypadku terminów skarga i zażalenie, które w słowniku Moguša brzmią identycznie jako tužba. Dlatego słowniki tylko częściowo pomagają $\mathrm{w}$ pracy translatorskiej. W tym przypadku tłumacz musi skorzystać z pomocy wyszukiwarek internetowych. Zawarte w nich dane są bardziej wiarygodne i częściej modyfikowane, ponieważ thumacz może sprawdzić termin, jego częstotliwość oraz liczbę wystąpień na stronie. Główną zaletą internetu są też fora dyskusyjne dla tłumaczy czy bazy terminologiczne, dzięki którym można znacznie skrócić czas na odnalezienie 
wyszukiwanego terminu. Ponadto funkcjonalność tłumaczenia jest zwiększona, ponieważ tłumacz uzyskuje wgląd $\mathrm{w}$ to, jak na przykład inni tłumacze rozwiązali podobne problemy terminologiczne i czy istnieje $\mathrm{w}$ bazach odzwierciedlenie określonego terminu. Różnego rodzaju proste internetowe translatory online, wykorzystywane często przez osoby o różnych profesjach - od inżynierów, prawników, lekarzy po studentów bez wiedzy lingwistycznej, często pozostają bezużyteczne przy translacji prawnej.

\section{Podsumowanie.}

Jak powszechnie wiadomo sama znajomość języków nie jest wystarczająca do wykonania poprawnego przekładu. Proces ten jest bowiem czynnością złożoną, opartą przede wszystkim na gruntownym $i$ wszechstronnym warsztacie opartym na zrozumieniu tekstu oryginału począwszy a skończywszy na gotowym produkcie. Jak trafnie zauważyła Karolina Nartowska: „Tłumacz sądowy musi (...) nabyć i rozwinąć specyficzne kompetencje i umiejętności, których programy studiów translatorycznych obecnie nie obejmują, a moduły dotyczące kształcenia tłumaczy sądowych, przede wszystkim w zakresie thumaczenia ustnego, praktycznie nie istnieją (Nartowska 2018: 178).

Jak widać, bardzo ważną kwestią w podnoszeniu warsztatu tłumaczy są specjalistyczne szkolenia. W Polsce prowadzą je różnego rodzaju stowarzyszenia. Wiodącą rolę odgrywa tu jednak Towarzystwo Thumaczy Przysięgłych i Specjalistycznych TEPIS $\mathrm{z}$ siedzibą $\mathrm{w}$ Warszawie. Niestety $\mathrm{w}$ zakresie języka chorwackiego szkoleniom i webinariom poświęca się nadal zbyt mało miejsca i uwagi. Warsztaty takie muszą obejmować nie tylko zakres wiedzy ogólnej, ale również specjalistycznej, mającej kluczowy czynnik na wartość tłumaczonego tekstu czy dokumentu. Kolejnym i chyba kluczowym problemem jest brak fachowych słowników, które niewątpliwie skróciłyby czas i ułatwiłyby pracę tłumaczom przysięgłym zarówno w Polsce, jak i Chorwacji.

\section{Summary}

The above article is devoted to the role of a sworn translator and translation, with particular attention to the specificity of a legal terminology rendering. It was based on personal competence, translation experience, and interdisciplinary knowledge. A process of translation begins with an understanding of the original source text and ends in achieving a final result, that is committing a diligent translation. A legal 
translation bears similarity to any other rendering but is very specific in the way that it brings together not only lingual but also a broader understanding as far as legal knowledge and that of history is concerned. A translator has to bear in mind the fact that combined knowledge both of law and history is required to be applied in the most appropriate manner.

\section{Literatura}

Barak, A. Purposive Interpretation of Law. Princeton: Princeton University Press, 2005.

Groot, de G. R. Rechtsvergleichung als Kerntätigkeit bei der Übersetzung juristischer Terminologie. In: Sprache und Recht. Berlin-New York, 2005.

Jopek-Bosiacka, A. Przekład prawny i sqdowy. Warszawa: PWN, 2009.

Juszkiewicz, H. Małoletni, młodociani, nieletni ... czyli polska terminologia prawna związana z wiekiem w kontekście tłumaczeń angielsko-polskich. Biuletyn Koła Naukowego Ttumaczeń Specjalistycznych Uniwersytetu Gdańskiego. Linguana, nr 4. Wydanie specjalne: Ttumaczenia prawne i prawnicze. 2012.

Kadrić, M. Dolmetschen bei Gericht. Erwartungen - Anforderungen - Kompetenzen. Wien: facultas, 2009.

Kubacki, A. D. Odpowiedzialność zawodowa tłumaczy przysięgłych. Język. Komunikacja. Informacja. Tom 3, 2008, s. 149-161.

Nartowska, K. Tłumacz i działanie translatorskie w sądzie. Comparative Legilinguistics International Journal for Legal Communication vol. 13, 2013.

Nartowska, K. Ustawa o zawodzie tłumacza przysięgłego a tłumaczenie sądowe w Polsce. Rocznik przekładoznawczy. 2018 (3/13), s. 171-193.

Pieńkos, J. Podstawy przekładoznawstwa. Od teorii do praktyki. Kraków. Kantor Wydawniczy Zakamycze, 2003.

Wojnicki, J. Dylematy przeobrażeń ustrojowych w Republice Chorwacji. Republika Chorwacji. Polityka wewnętrzna i międzynarodowa. 2014, s. 13-26. 